\title{
Differentiation of Pseudomonas solanacearum, Pseudomonas syzygii, Pseudomonas pickettii and the Blood Disease Bacterium by partial 16S rRNA sequencing: construction of oligonucleotide primers for sensitive detection by polymerase chain reaction
}

\author{
S. E. Seal, ${ }^{1 *}$ L. A. Jackson, ${ }^{1}$ J. P. W. Young ${ }^{2} \dagger$ and M. J. Daniels ${ }^{1}$ \\ ${ }^{1}$ The Sainsbury Laboratory, John Innes Centre, Norwich Research Park, Norwich NR4 7UH, UK \\ ${ }^{2}$ John Innes Institute, Norwich Research Park, Norwich NR4 7UH, UK
}

(Received 11 November 1992; revised 24 February 1993; accepted 4 March 1993)

\begin{abstract}
The sequence of a 292 bp segment of the DNA encoding 16S rRNA (corresponding to positions 44-337 of the Escherichia coli 16S rRNA sequence) was determined for each of 40 Pseudomonas solanacearum, four banana Blood Disease Bacterium, three $P$. syzygii and two $P$. pickettii strains. Phylogenetic relationships derived from comparison of these sequences to each other, and to equivalent 16S rRNA gene sequences from other bacteria present in the EMBL databank, conform well with those obtained previously by DNA-DNA/rRNA hybridization experiments. The 16S rRNA sequence of the Blood Disease Bacterium was identical over the 292 bp to one of the four sequence groups of $\boldsymbol{P}$. solanacearum, suggesting that these pseudomonads are more closely related to each other than to $P$. syzygii or $P$. pickettii. Sequence data comparisons allowed construction of an oligonucleotide specific for $P$. solanacearum, $P$. syzygii and the Blood Disease Bacterium. Use of the specific oligonucleotide with a non-specific oligonucleotide in the polymerase chain reaction enabled 1-10 cells of bacteria in this group to be detected after 50 rounds of amplification by visualizing a $287-288$ bp product on agarose gels.
\end{abstract}

\section{Introduction}

The species Pseudomonas solanacearum, P. pickettii and $P$. syzygii fall within the same DNA-DNA homology group of Pseudomonas rRNA group II (De Vos \& De Ley, 1983; Palleroni et al., 1973; Palleroni, 1984; Roberts et al., 1990), which contains many pathogenic pseudomonads. $P$. solanacearum causes bacterial wilt of a large range of crops in the tropics, subtropics and warm temperate regions of the world. P. pickettii and $P$. syzygii are closely related species (Ralston et al., 1973; Roberts

*Author for correspondence. Present address: Natural Resources Institute, Central Avenue, Chatham Maritime, Kent ME4 4TB, UK. Tel. 0634 880088; fax 0634880066.

$\dagger$ Present address: Department of Biology, University of York, Heslington, York YO1 5DD, UK.

Abbreviations: PCR, polymerase chain reaction; BDB, Blood Disease Bacterium; RFLP, restriction fragment length polymorphism; rDNA, DNA encoding ribosomal RNA.

The nucleotide sequence data reported in this paper have been submitted to EMBL and have been assigned the accession numbers X70344-X70350. et al., 1990) which cause opportunistic infections in humans and Sumatra disease of cloves (Syzygium aromaticum), respectively. Blood Disease Bacterium (BDB) strains affect certain members of the Musaceae in Indonesia (Gäumann, 1923; Eden-Green \& Sastraatmadja, 1990), giving rise to symptoms similar to bacterial wilt of banana (termed Moko disease), but with pronounced exudation of a reddish-coloured bacterial ooze. Whether the BDB should be classified as a separate species (e.g. ' $P$. celebense' as originally proposed by Gäumann, 1923) or as a new subgroup of $P$. solanacearum remains unresolved. BDB strains, like $P$. syzygii (and to a more limited extent $P$. pickettii), are related to $P$. solanacearum serologically as well as by DNA-DNA homology (Roberts et al., 1990; Hayward, 1991; Cook et al., 1991), and show similar fingerprints after polymerase chain reaction (PCR) amplification with tRNA consensus primers (Seal et al., 1992c). They are, however, easily differentiated by host range, cultural and physiological properties (Eden-Green \& Sastraatmadja, 1990).

$P$. solanacearum strains represent a heterogeneous group that has been subdivided into five races based on host range, and five biovars based on catabolic properties 
Table 1. Bacterial strains

\begin{tabular}{|c|c|c|c|c|c|}
\hline Strain & Race* & Biovar $\dagger$ & Origin & Contributor§ & Group $\|$ \\
\hline \multicolumn{6}{|c|}{$\begin{array}{l}\text { Pseudomonas } \\
\text { solanacearum }\end{array}$} \\
\hline UW25 & 1 & 1 & Tomato, USA, Kelman K60 & W & 3 \\
\hline UW26 & 1 & 1 & Tomato, USA, Kelman K74 & W & 3 \\
\hline UW256 & 1 & 1 & Potato, Costa Rica, Gonzalez G-7 & W & 2 \\
\hline UW275 & 1 & 1 & $\begin{array}{l}\text { Melampodium perfoliatum, Costa Rica, } \\
\text { Sequeira }\end{array}$ & W & 2 \\
\hline UW278 & 1 & 1 & Tobacco, Mexico, Fucikovsky & W & 2 \\
\hline B9043 & 1 & 1 & Clove, Indonesia, Eden-Green & $\mathbf{R}$ & 4 \\
\hline R142 & & 2 & Clove, Indonesia, Eden-Green S710 & $\mathbf{R}$ & 4 \\
\hline R361 & & N2 & Potato, Peru, Turkensteen CIP61 & $\mathbf{R}$ & 1 \\
\hline R568 & & N2 & Potato, Brazil, Neto 172 , CIP226 & $\mathbf{R}$ & 1 \\
\hline R578 & & $\mathrm{N} 2$ & Eggplant, Peru, Aley SR130 & $\mathbf{R}$ & 1 \\
\hline R583 & & N2 & Potato, Peru, Martin CIP172 & $\mathbf{R}$ & 1 \\
\hline S825 & 1 & 3 & Clove, Indonesia, Eden-Green & $\mathbf{R}$ & 1 \\
\hline S925 & 1 & 3 & Clove, Indonesia, Eden-Green & $\mathbf{R}$ & 1 \\
\hline T451 & 1 & 3 & $\begin{array}{l}\text { Zingiber cassumunar, Indonesia, } \\
\text { Supriadi }\end{array}$ & B & 1 \\
\hline T456 & 1 & 3 & Castor bean, Indonesia, Supriadi & B & 1 \\
\hline T496 & 1 & 3 & Croton, Indonesia, Subandiah 1605WS & B & 1 \\
\hline UW8 & 1 & 3 & $\begin{array}{l}\text { Eupatorium odoratum, Costa Rica, } \\
\text { Sequeira K201 }\end{array}$ & W & 1 \\
\hline UW147 & 1 & 3 & Tobacco, Australia, Hayward S240 & W & 1 \\
\hline UW380 & 1 & 3 & Olive, China, He OPS2 & W & 1 \\
\hline GMI1000 & 1 & 4 & Tomato, Guyana, Boucher et al. (1985) & A & 1 \\
\hline PD1682 & 1 & 4 & Ginger, Thailand, Sardsud & $\mathbf{J}$ & 1 \\
\hline R27 & 1 & 4 & Potato, Indonesia, Hayward B050 & $\mathbf{R}$ & 1 \\
\hline UW74 & 1 & 4 & Potato, Sri Lanka, CMI \#B2861 & W & 1 \\
\hline UW151 & 1 & 4 & Ginger, Australia, Hayward S244 & W & 1 \\
\hline UW378 & 1 & 4 & Olive, China, He OPS1 & W & 1 \\
\hline UW361 & 1 & 5 & Mulberry, China, He MPS4 & W & 1 \\
\hline UW373 & 1 & 5 & Mulberry, China, He MPS2 & W & 1 \\
\hline UW160 & 2 & 1 & Plantain, Peru, Sequeira S253 & W & 2 \\
\hline UW167 & 2 & 1 & Banana, Costa Rica, Sequeira K160 & W & 1 \\
\hline GMI8133 & 2 & 1 & Plantain, Colombia, Thurston \$210 & A & 3 \\
\hline JEBUG2 & $2 \mathrm{~A}$ & 1 & Banana, Philippines, Elphinstone & $\mathbf{R}$ & 1 \\
\hline JEMOK 7 & 2 & 1 & Banana, Philippines, Elphinstone & $\mathrm{R}$ & 1 \\
\hline R207 & 2 & 1 & Banana, Belize, Black ARI-S & $\mathbf{R}$ & 2 \\
\hline R273 & 2 & 1 & Banana, Trinidad, Rajnauth SFR1 & $\mathbf{R}$ & 2 \\
\hline R484 & $2 \mathrm{~A}$ & 1 & Banana, Philippines, Eden-Green P14 & $\mathbf{R}$ & 1 \\
\hline R570 & 2 & 1 & Plantain, Costa Rica, CIP19, UW155 & $\mathbf{R}$ & 1 \\
\hline K46 & 3 & 2 & Potato, Kenya, Forde & $\mathbf{R}$ & 1 \\
\hline P2 & 3 & 2 & Potato, Philippines, Seal & $\mathrm{D}$ & 1 \\
\hline UW19 & 3 & 2 & Potato, Colombia, Thurston S205 & W & 1 \\
\hline UW23 & 3 & 2 & Potato, Israel, Volcani K56 & $\mathrm{W}$ & 1 \\
\hline \multicolumn{6}{|c|}{$\begin{array}{l}\text { Blood disease } \\
\text { bacterium }\end{array}$} \\
\hline R229 & & & Banana, Indonesia, Eden-Green T389 & $\mathbf{R}$ & 4 \\
\hline R230 & & & Banana, Indonesia, Eden-Green T334 & $\mathbf{R}$ & 4 \\
\hline R231 & & & Banana, Indonesia, Eden-Green T391 & $\mathbf{R}$ & 4 \\
\hline T340 & & & Banana, Indonesia, Eden-Green & $\mathbf{R}$ & 4 \\
\hline \multicolumn{6}{|c|}{ Pseudomonas pickettii } \\
\hline \multirow{2}{*}{\multicolumn{3}{|c|}{$\begin{array}{l}\text { E1625 } \\
\text { NC11149 }\end{array}$}} & Soil/potato, Ethiopia, Wondimagegne & $\mathrm{E}$ & \\
\hline & & & & $\mathrm{N}$ & \\
\hline \multicolumn{6}{|c|}{ Pseudomonas syzygii } \\
\hline \multicolumn{3}{|c|}{ R001 } & Clove, Indonesia, Eden-Green & $\mathbf{R}$ & \\
\hline \multicolumn{3}{|l|}{ R004 } & Hindola fulva, Indonesia, Eden-Green & $\mathbf{R}$ & \\
\hline \multicolumn{3}{|l|}{ R170 } & Clove, Indonesia, Eden-Green & $\mathbf{R}$ & \\
\hline
\end{tabular}

$* 2 \mathrm{~A}$, bugtok strains.

$\dagger \mathrm{N} 2$, new biovar 2 (lowland strains).

$\ddagger$ Host, country, isolator and alternative strain designation are given.

$\S$ Strains were contributed by: A, M. Arlat \& P. Barberis, CNRS-INRA, Auzeville, CastanetTolosan Cedex, France; B, Supriadi, Balai Penelitian Tanaman Rempah dan Obat, J1. Cimanggu 3, Bogor, Indonesia; D, M. Daniels \& S. Seal, The Sainsbury Laboratory, Norwich, UK; E, 
(see Hayward, 1991). Inconsistencies in DNA-DNA homologies of strains of $P$. solanacearum with each other have been noted by Palleroni \& Doudoroff (1971) and by Roberts et al. (1990). It was suggested by Roberts $e t$ al. (1990) that the relatedness between strains of $P$. solanacearum is less than that which would be expected within a species. Seal et al. $(1992 c)$ found that $P$. solanacearum strains gave rise to three 'fingerprint' groups after PCR amplification with tRNA consensus primers. Welsh \& McClelland (1991) found that these primers generated PCR fingerprints which showed little variation within a species and between closely related species. The division of $P$. solanacearum strains into these three PCR fingerprint groups conforms well to the major divisions made in the 33 RFLP groups by Cook et al. (1991) (Seal et al., 1992c). Further studies of the taxonomic relationships within a large number of strains of $P$. solanacearum are required to clarify relationships of subgroups of $P$. solanacearum to each other, to the BDB, and to $P$. syzygii.

Traditionally, classification of bacteria has been based on similarities in phenotypic characteristics. However, classification based on these criteria does not necessarily correlate well with evolutionary relationships defined by macromolecular comparisons (Woese, 1987). Of the macromolecules used for phylogenetic analyses, the $16 \mathrm{~S}$ rRNA molecule has become particularly valuable in recent years for ascertaining the interrelationships of bacteria (Woese, 1987). This is not only because of its high information content, conservative nature and universal distribution, but also due to the rapidly expanding 16S rRNA sequence data accessible through gene databanks that can be used for phylogenetic analysis. With the development of the PCR and techniques for the direct sequencing of amplified DNA (Innes et al., 1988; Winship, 1989), rRNA-encoding DNA (rDNA) sequences can now be obtained relatively quickly. The aim of this study was to ascertain the phylogenetic relationships of subgroups within $P$. solanacearum to each other and to closely related BDB strains, $P$. syzygii and $P$. pickettii. To this end, primers designed by Young et al. (1991), which amplify a $\sim 300 \mathrm{bp}$ fragment of most bacterial 16S rDNAs, were used. The amplified region represents a relatively variable part of the 16S rRNA and thus has a high density of information, especially for comparisons of close relatives (Young et al., 1991). Phylogenetic relationships between species of the alpha proteobacteria deduced from this part of the molecule are similar to those derived from sequences of the entire 16S rRNA molecule (Young et al., 1991).

Sequences of $16 \mathrm{~S}$ rDNA genes are often speciesspecific and are present as multiple copies in microbial genomes. Hence they make excellent targets for identification of bacteria at the species level. Hybridization with short oligonucleotide labelled probes to species-specific sequences within the 16S rRNA molecule is used often as an identification procedure (Amann et al., 1990; DeLong et al., 1989; Giovannoni et al., 1988; Zarda et al., 1991). Recently, the corresponding specific rDNA sequences have been used as the targets for PCR amplification with complementary oligonucleotide primers. Amplification in the order of a million-fold can be achieved using PCR technology, which has resulted in specific detection of a single bacterial cell becoming feasible. Diagnostic tests based on specific PCR amplification of plant pathogens from environmental samples have shown that rapid detection of very low numbers of the pathogen can be achieved without the need for culturing (Ahrens \& Seemüller, 1992; Bereswill et al., 1992; Schesser et al., 1991; Seal et $a l ., 1992 b$ ). Rapid, highly sensitive diagnostic tests for $P$. solanacearum are required for quarantine and planting material certification purposes, as this pathogen can infect potato, tomato, ginger and banana without inducing symptoms.

In this paper we report the construction of a primer specific to the 16S rDNA of $P$. solanacearum, the BDB and $P$. syzygii, which enables more sensitive detection by PCR amplification of $P$. solanacearum in culture and potato tubers than previously achieved with ELISA, nucleic acid probes and PCR primers (Seal et al., $1992 a, b$ ).

\section{Methods}

Bacterial strains. The characteristics of the strains tested in this study are shown in Table 1.

Preparation of PCR-amplifiable DNA. All strains were grown overnight in NYGB (Daniels et al., 1984) at $28^{\circ} \mathrm{C}$ with shaking, and bacterial DNA was isolated by the method of Boucher et al. (1987), which involves lysis with Sarkosyl, proteinase $\mathrm{K}$ treatment, phenol/ chloroform extraction and ethanol precipitation. Alternatively, whole $P$. solanacearum cells could be used to provide a template for PCR amplification, but the cultures had to be grown on MM minimal

E. Wondimagegne, University of East Anglia, Norwich, UK; J, J. Janse, Plant Protection Service, Bacteriology Dept, 6700 HC Wageningen, The Netherlands; N, National Collection of Type Cultures, London, UK; R, S. Eden-Green, J. Elphinstone \& S. Forde, Rothamsted Experimental Station, Harpenden, Hertfordshire, UK; W, D. Cook \& L. Sequeira, Plant Pathology Dept, University of Wisconsin-Madison, Madison, USA

$\| P$. solanacearum sequencing group. 
medium (Boucher et al., 1985) to ensure adequate lysis of the cells. Lysis was performed by boiling $100 \mu \mathrm{l}$ of an overnight MM culture (or a loopful of cells from a colony resuspended in $100 \mu 1$ sterile distilled water) for $5 \mathrm{~min}$. After cooling to room temperature $2 \mu$ of the boiled culture was used per reaction without further treatment.

To determine the sensitivity of PCR detection, $100 \mu$ samples of $10-$ fold dilutions of exponentially growing MM cultures were plated out on NYGA (Daniels et al., 1984), incubated at $28^{\circ} \mathrm{C}$ for $2-3 \mathrm{~d}$ and colonies counted. Samples $(100 \mu \mathrm{l})$ of the 10 -fold dilutions of MM cultures were also boiled as described above, and aliquots used for PCR amplification. This enabled a calculation of the approximate number of lysed boiled cells added to the PCR reactions.

PCR amplification. The primers used were $\mathrm{Y} 1$ and $\mathrm{Y} 2$, designed by Young et al. (1991) to amplify a partial segment (corresponding to positions 40-337 of Escherichia coli 16S rRNA) of most DNAs encoding 16S rRNA. PCR amplifications were performed using DNA thermal cyclers (Perkin Elmer Cetus). Reaction volumes were $100 \mu \mathrm{l}$ and contained $1 \times \mathrm{PCR}$ buffer $\left[10 \mathrm{mM}\right.$-Tris $/ \mathrm{HCl} \mathrm{pH} 8.3$ at $25^{\circ} \mathrm{C}$, $50 \mathrm{~mm}-\mathrm{KCl}, 1.5 \mathrm{~mm}-\mathrm{MgCl}_{2}, 0.001 \%$ (w/v) gelatin (Sigma G-2500), $0.05 \%$ (v/v) Nonidet P40 (Sigma N-3516), 0.05\% (v/v) Tween 20 (Sigma P-1379)], 0.2 mM of each dNTP, $1 \mathrm{U}$ Taq polymerase, $1 \mu \mathrm{M}$ of primers Y1 (5'TGGCTCAGAACGAACGCGGCGGC3') and Y2 (5'CCCACTGCTGCCTCCCGTAGGAGT3'), and template DNA (either 10-20 ng of purified DNA or $2 \mu 1$ of boiled MM-culture). Each reaction was overlaid with two drops of light mineral oil (Sigma M3516), and heated to $96^{\circ} \mathrm{C}$ for 2 min. Reactions were then cycled 35 times through phases of denaturation $\left(94^{\circ} \mathrm{C}\right.$ for $\left.20 \mathrm{~s}\right)$, annealing $\left(61^{\circ} \mathrm{C}\right.$ for $20 \mathrm{~s}$ ) and extension $\left(72{ }^{\circ} \mathrm{C}\right.$ for $\left.30 \mathrm{~s}\right)$, followed by a final period of $10 \mathrm{~min}$ at $72^{\circ} \mathrm{C}$. Samples $(5 \mu \mathrm{l})$ of reaction mixtures were examined by electrophoresis using $2 \%$ (w/v) agarose gels (Sigma A-6013) and bands revealed by staining with ethidium bromide.

For specific PCR amplification of samples containing DNA of the $P$. solanacearum, $P$. syzygii and BDB group, the non-specific primer $\mathrm{Y} 2$ was used together with a specific primer OLI1 (5'GGGGGTAGCTTGCTACCTGCC $3^{\prime}$ ). Reactions were as described above using $1 \mu \mathrm{M}$ of each primer $\mathrm{Y} 2$ and OLI1, and $50 \mu 1$ reaction volumes. Reaction mixtures were cycled in a similar fashion to Y1-Y2 samples, but an annealing temperature of $68{ }^{\circ} \mathrm{C}$ was used. For samples containing approximately less than $100 P$. solanacearum, $P$. syzygii or BDB cells, the number of amplification rounds was increased from 35 to 50 cycles. Reactions containing $P$. solanacearum, $P$. syzygii or BDB DNA gave a single product of 288 bp ( 287 bp for $P$. syzygii), visible when $15 \mu \mathrm{l}$ of the $50 \mu \mathrm{l}$ reaction was examined by electrophoresis.

$D N A$ sequencing. Products generated by PCR amplification with primers $\mathrm{Y} 1$ and $\mathrm{Y} 2$ were purified by using Qiagen 'tip-5' columns (Diagen, Düsseldorf, Germany) according to the manufacturer's protocol. Purified products were sequenced in both directions using the method and $c^{7}$ dITP reagents of a T7 sequencing kit (Pharmacia LKB), with the exception that the template was denatured together with the primer by boiling followed by rapid cooling in dry ice. Sequences were aligned with each other and with 16S rRNA databank sequences of other alpha and beta subgroup bacteria, using the Wisconsin programs (Devereux et al., 1984). All positions where there were base changes or other mismatches were checked by repeating the sequencing of a PCR reaction product from an independent DNA preparation of the relevant strain.

\section{Results and Discussion}

Sequence data for all strains are shown in Fig. 1. Alignments can be made reliably due to high conservation of several positions and the secondary structure of the 16S rRNA molecule (Woese, 1987). It is clear from the sequence and its predicted secondary structure (Fig. 2 ) that the species $P$. solanacearum, $P$. syzygii, $P$. pickettii and the BDB belong to the beta subdivision of the purple bacteria; e.g. a $\mathrm{U}$ at position 7 (corresponding to E. coli position 50 ) and the stem-loop between positions 152 and 175 are characteristic of the beta subdivision (Woese, 1987).

PCR amplification with primers $\mathrm{Y} 1$ and $\mathrm{Y} 2$ yielded a product of $292 \mathrm{bp}$ for all $40 P$. solanacearum and four BDB strains, a 291 bp product for the three $P$. syzygii strains and a 294 bp product for the two $P$. pickettii strains studied. Generally, there is very little variation in the 16S rRNA sequence of strains within a species (Woese, 1987). However, within the $292 \mathrm{bp}$ amplified from $P$. solanacearum strains, there were two variable sites I and II (positions 122 and 224 respectively; Fig. 2), each of which showed one of two possible bases. This resulted in the $40 P$. solanacearum strains studied falling into four sequence groups: group 1 has an $\mathrm{A}$ at position $\mathrm{I}$ and a $\mathrm{C}$ at position II, group 2 has an $\mathrm{A}$ and $\mathrm{T}$, group $3 \mathrm{a} G$ and $T$, and group $4 \mathrm{a} G$ and $\mathrm{C}$ respectively. The group of each strain sequenced is shown in Table 1 . The sequence data thus support other nucleic-acid-based studies of $P$. solanacearum (Cook et al., 1989, 1991; Palleroni \& Doudoroff, 1971; Roberts et al., 1990; Seal et al., 1992c) that show it to be a heterogeneous species.

The groups formed within $P$. solanacearum by 16S rRNA sequencing are in general agreement with those based on RFLP analysis (Cook et al., 1989, 1991) and by PCR amplification with tRNA consensus primers (Seal et al., 1992c), although the subdivision of biovar 1 and 2 strains into groups is not identical for these three classification methods. That is, the RFLP groups within RFLP division II (biovar 1 and 2 strains) belong to either tRNA fingerprint type I or II, and rRNA sequence groups $1,2,3$ or 4 . Biovar 3, 4 and 5 strains belong to RFLP division I, tRNA fingerprint type III, and form part of 16S rRNA sequence group 1. Although these three recent methods of classification of $P$. solanacearum strains do not support exactly the same grouping of strains, they all divide the species very differently from the traditional race classification system (Buddenhagen et al., 1962), in which the quite different members of biovars 1,3 and 4 are placed within a single race. The three methods of classification based on nucleic acid properties are consistent with a common Australasian evolutionary origin of biovars 3,4 and 5 , but uncertainty remains on evolutionary relationships within biovar 1 and 2 strains of American origin.

The sequence of the BDB rRNA is identical over the $292 \mathrm{bp}$ to that of $P$. solanacearum group 4, confirming that this is a very close relative of $P$. solanacearum as previously suggested (Eden-Green \& Sastraatmadja, 1990; Cook et al., 1991). Group 4 contains only two $P$. 
P. solan.1 P.solan. 2

P.solan. 3

P.solan.4

P.syzygil

P.pick. 1

P.pick. 2

A.eutrop.

P. cepacia

P.solan.1

P.solan.2

P. solan. 3

P.solan. 4

P.syzygil

P.pick. 1

P.pick.2

A. eutrop.

P.cepacia

P.solan. 1

P.solan. 2

P.solan. 3

P.solan.4

P.syzygii

P.pick. 1

P.pick. 2

A. eutrop.

P. cepacta

P.solan.1

P.solan.2

P.solan. 3

P. solan. 4

P.syzygii

P.pick. 1

P.pick. 2

A.eutrop.

P. cepacia

P.solan.
P.solan.2
P. solan. 3
P.solan. 4
P.syzygil
P.pick. 1
P.pick.2
A.eutrop.
P. cepacia

1 ATGCCTIACA CATGCAAGTC GAACGGCAG. . CGgGGTAG CTTG. CTACC TGCCGgCGAG (1) -- -

61

120 TGGCGAACGG GTGAGTAATA CATCGGAACG TGCCCTGTAG TGGGGGATAA CTAGTCGAAA

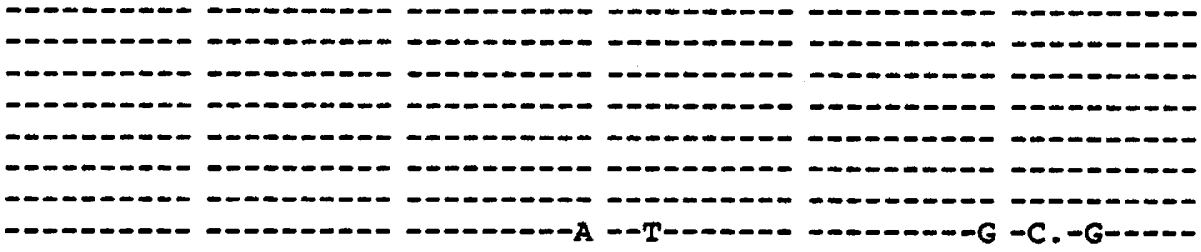

121

180 GACTAGCTAA TACCGCATAC GACCTGAGGG TGAAAGTGGG GGACCGCAAG GCCTCATGCT

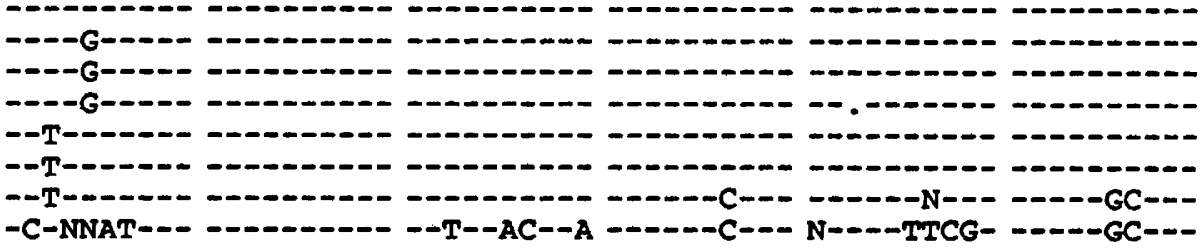
181 240 ATAGGAGCGG CCGATGTCTG ATTAGCTAGT TGGTGGGGTA AAGGCCCACC AAGGCGÁCGA

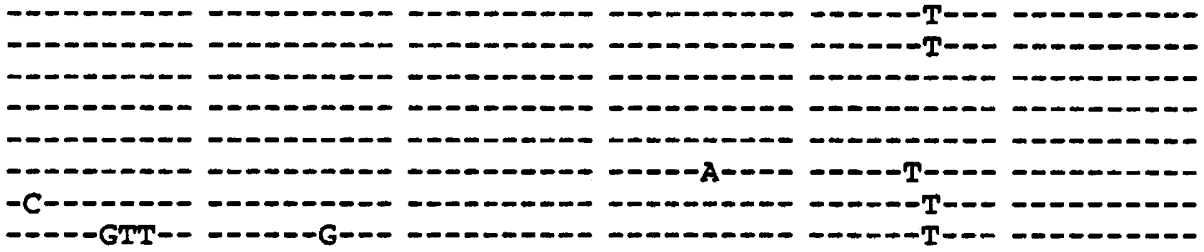
TCAGTAGCTG GTCTGAGAGG ACGATCAGCC ACACTGGGAC TGAGACACGG CCCAG

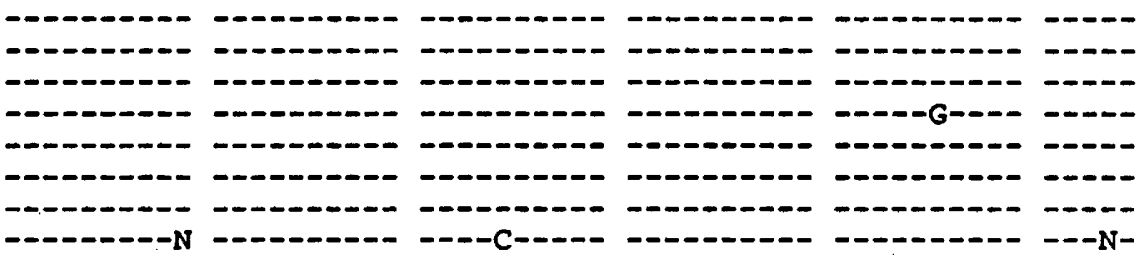

Fig. 1. Aligned sequences of part of the 16S rRNA gene of strains of $P$. solanacearum ( $P$. solan. 1 to $P$. solan. 4) (see Table 1 for strains in sequence groups 1 to 4), Blood Disease Bacterium (P. solan. 4), P. syzygii, P. pickettii (P. pick. $I$ and $P$. pick. 2 ; strains E1625 and NC11149, respectively), Alcaligenes eutrophus (A. eutrop.), and Pseudomonas cepacia. The sequences shown represent the region amplified by primers $\mathrm{Y} 1$ and $\mathrm{Y} 2$, but exclude the primer sequences. Dashes indicate that the base is identical to that found in $P$. solanacearum group 1 ( $P$. solan. 1 ). Dots indicate alignment gaps. The sequences $A$. eutrop. and $P$. cepacia are shown for comparison, and represent part of sequences AERGSSA and PCRRDA respectively, which are present in the EMBL DataBank.

solanacearum strains (B9043 and R142) of the 40 sequenced. Both these strains were isolated from clove in Indonesia and are atypical in other characteristics: B9043 is a race 1 biovar 1 strain - such strains are not commonly isolated in Asia; and R142 is a biovar 2 strain but not of race 3 (to date, biovar 2 strains in Asia have been isolated only from potato and all were race 3 strains). Strains B9043 and R142 also show the same fingerprint type as the BDB when amplified with tRNA consensus primers (Seal et al., 1992c), but have nutritional properties and a host range typical of $P$. solanacearum. The similarity in $16 \mathrm{~S}$ rRNA sequence and 


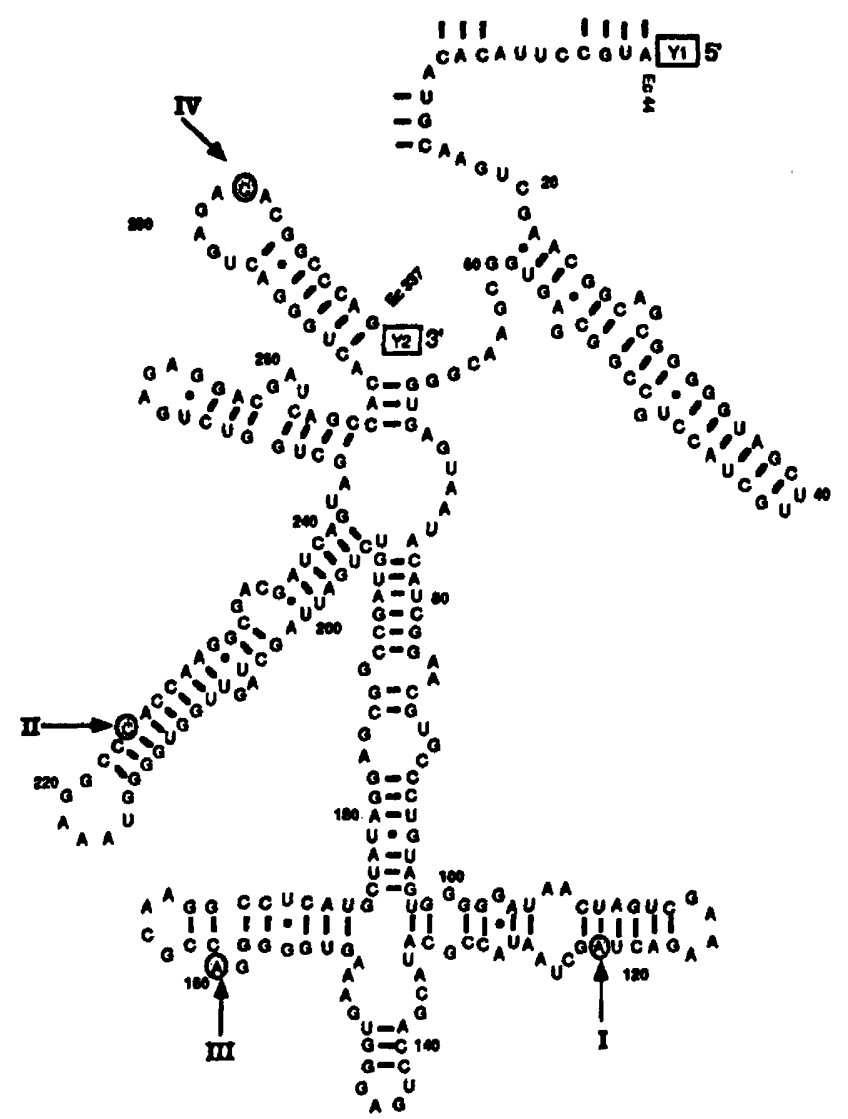

Fig. 2. Predicted secondary structure of the part of the $16 \mathrm{~S}$ rRNA molecule encoded by the sequence determined for $P$. solanacearum. The secondary structure was developed from that published for $E$. coli (Woese, 1987). Numbers prefixed by 'Ec' are corresponding positions in the complete $E$. coli sequence. Arabic numbers indicate the approximate position in the sequence alignment of Fig. 1. Roman numerals indicate the positions that are variable in the $P$. solanacearum, $P$. syzygii and BDB strains studied. The sequence immediately adjacent to primer $\mathrm{Y} 1$ interacts with parts of the molecule not shown.

tRNA PCR fingerprints suggests that it may not be appropriate to consider the $\mathrm{BDB}$ as a separate species. However no 'Moko' strain falls into the same 16S rRNA sequence group as the BDB strains, and hence it may be worthwhile to preserve the distinction between these very similar pseudomonads that cause vascular infections of Musaceae. Sequencing more of the 16S rRNA molecule may clarify the taxonomic status of the BDB, although taxonomy should not be based on 16S rRNA sequence data alone. DNA from the BDB hybridized to some $P$. solanacearum DNA probes (Cook et al., 1991; Cook \& Sequeira, 1991), but not to many other probes, some of which appear to hybridize to sequences which are highly conserved in $P$. solanacearum strains (Seal et al., $1992 b$; S. E. Seal, unpublished results). Moreover, BDB strains have a different host range, and possess several physiological and nutritional characteristics quite distinct from P. solanacearum (Eden-Green \& Sastraatmadja, 1990; S. Eden-Green, unpublished results). A more detailed study, based on as wide a range of characteristics as possible, is required to resolve the relationship between the BDB and $P$. solanacearum.

$P$. syzygii shows a similar $16 \mathrm{~S}$ rRNA sequence to $P$. solanacearum group 4 , but is one base shorter in length (the base at position III in Fig. 2 is missing), and has a $\mathrm{G}$ rather than a $\mathrm{C}$ at position IV (Fig. 2). However, $P$. pickettii differs considerably from $P$. solanacearum and $P$. syzygii, notably between positions 30 and 54 . The two strains of $P$. pickettii used also differ from one another at positions 216 and 226. In separate studies, both $P$. syzygii and $P$. pickettii were shown to be close relatives of P. solanacearum (Roberts et al., 1990; Ralston et al., 1973). Partial 16S rRNA sequence data suggest that $P$. syzygii is phylogenetically closer to $P$. solanacearum than $P$. pickettii is, although an unambiguous phylogenetic tree cannot be determined from comparison of less than 300 bases of the 16S rRNA molecule. Both species showed greater sequence homology to $P$. solanacearum than Alcaligenes eutrophus and Pseudomonas cepacia (the sequences of which are included in Fig. 1 for comparison), which were previously shown to be related by DNA-rRNA hybridization studies (De Vos \& De Ley, 1983).

Two of the $40 P$. solanacearum strains studied, JEBUG2 and R484, are strains that cause 'bugtok' disease of cooking bananas in the Philippines. Bugtok disease was first reported by Roperos (1965) and is similar to Moko disease, except that symptoms are generally confined to the floral raceme and foliar symptoms are absent. Partial 16S rRNA sequence data support the inclusion of the bugtok bacterium within the species $P$. solanacearum, as suggested by cultural characteristics and RFLP patterns (S. E. Seal, unpublished results).

An oligonucleotide specific for the group $P$. solanacearum, $P$. syzygii and the $\mathrm{BDB}$ was constructed by comparing the partial $16 \mathrm{~S}$ rRNA gene sequences with equivalent sequences for other organisms present in the EMBL databank. Use of this specific primer, OLI1, together with the non-specific primer Y2 in PCR with an annealing temperature of $68^{\circ} \mathrm{C}$ allowed specific amplification of a single $287-288$ bp product. No visible PCR product was generated from strains of the closely related species $P$. pickettii, nor from strains of A. eutrophus, $P$. cepacia or 12 other bacterial species (data not shown). All 59 strains of the group $P$. solanacearum $-P$. syzygii-BDB tested, including 19 strains for which $r$ RNA sequence data were not obtained, produced the specific PCR product.

To determine the limit of detection of PCR amplification with primers $Y 2$ and OLI1, $5 \mu$ samples of boiled 10 -fold dilutions of exponentially growing cultures of three strains were used as a template for the PCR. 


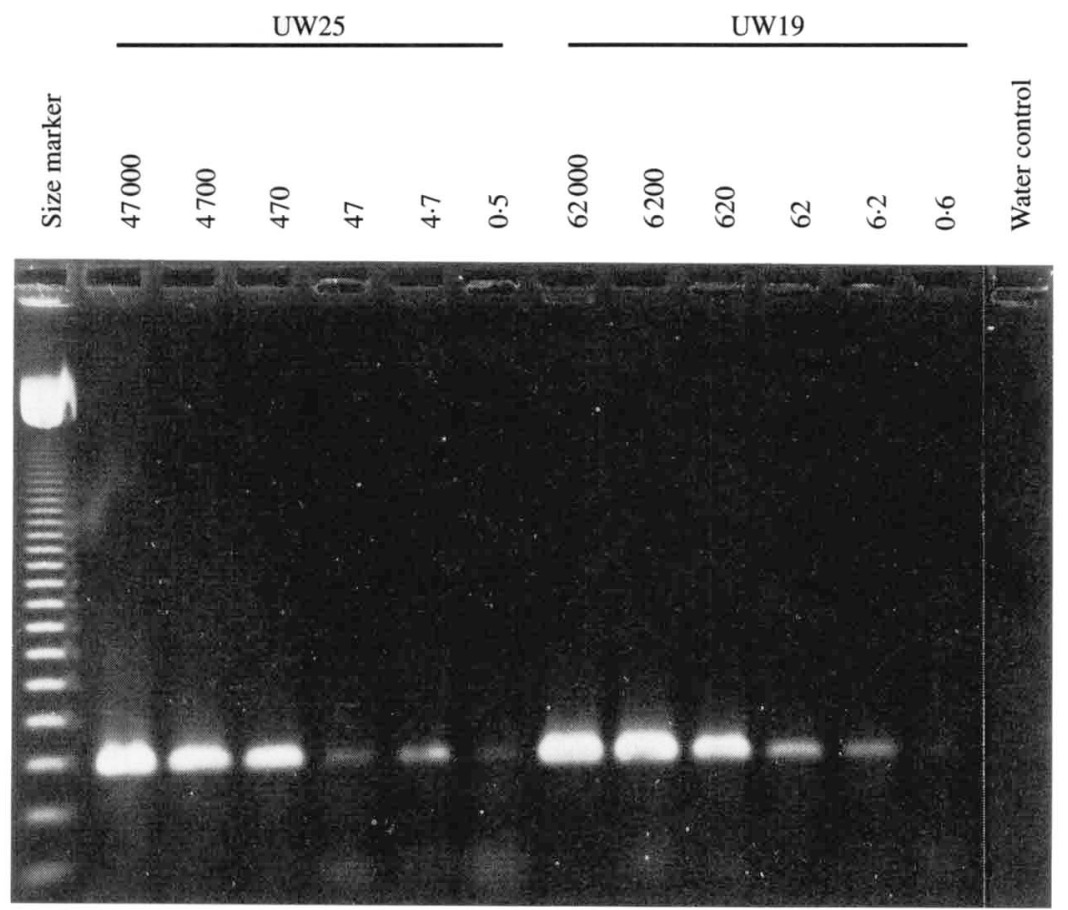

Fig. 3. Electrophoretic analysis of PCR-amplified product from boiled cells of two $P$. solanacearum strains, UW19 and UW25, using the primer pair OLI 1 and Y2 and 50 cycles of amplification. The size of the PCR product is $\sim 300$ base pairs. Tracks are labelled with the approximate number of cells used as template for the PCR.
After electrophoresis of $15 \mu \mathrm{l}$ aliquots of the PCR reactions (after 50 amplification rounds) the specific product could be seen easily on agarose gels from samples containing DNA from as few as six, five and two cells for strains UW19, UW25 and UW167 respectively (Fig. 3 and data not shown). The specific product could often be seen with a further 10-fold dilution of the bacterial samples, but this was not always reproducible. These numbers will be a slight overestimate of the detection sensitivity, as they have been derived from calculations of viable counts, and exponential cultures will contain DNA of both viable and non-viable cells. Nonetheless, the sensitivity achieved by this PCR detection test for $P$. solanacearum is greater than that achieved with the $P$. solanacearum-specific primer combination PS96-H/PS96-I (Seal et al., 1992b), which has a detection limit in the range of $10^{1}$ to $10^{2}$ cells, depending on the strain. Crude preparations from infected potato, tomato, ginger, eggplant and pepper plants have been tested by PCR with both primer pairs. The PCR tests successfully detected $P$. solanacearum in all samples known to be infected (Seal et al., 1992a). Detection of $P$. solanacearum in field samples by PCR using primer combination OLI1-Y2 was more sensitive than using primers PS96-H and PS96-I, some samples only generating a visible PCR product with the former primers (unpublished results). However, PCR amplification with primers OLI1 and Y2 is not specific for $P$. solanacearum, products also being produced from samples containing either P. syzygii or BDB DNA. In practice, this should not diminish the usefulness of this PCR test as a diagnostic procedure for $P$. solanacearum, as $P$. syzygii and the BDB are only recorded at present in clove and banana in Indonesia. Alternatively, samples could be tested separately with both primer pairs to determine if the samples contained $P$. solanacearum, $P$. syzygii or BDB DNA. The host of origin of the sample will allow differentiation of $P$. syzygii and BDB, neither of which produces the $P$. solanacearum-specific $P C R$ product with primers PS96-H and PS96-I.

The OLI1-Y2 PCR test will be a useful tool for investigating various questions regarding the epidemiology of the diseases caused by $P$. solanacearum, $P$. syzygii and the BDB which have remained unanswered due to the lack of a rapid sensitive test. The test should also permit more critical studies on the ecology of $P$. syzygii, which in the past have been hindered because the organism is slow growing and difficult to culture.

Latent bacterial wilt infection of symptomless potato tubers in Burundi was demonstrated, using the primer combination OLI1-Y2 and 50 PCR amplification rounds (Seal et al., 1992a). This PCR test may have application in quarantine laboratories in countries where $P$. solanacearum is not present. The test can be completed in less than $5 \mathrm{~h}$, and therefore has a great advantage over the traditional methods which involve cultivation of the bacteria. Speed is essential for quarantine laboratory assessment to limit the time that shipments wait at ports of entry. Careful inspection of potato tubers for $P$. solanacearum infection is important not only for tropical and subtropical countries, but also for temperate countries, where bacterial wilt can cause significant 
losses to potato crops, as illustrated in Sweden (Olsson, 1976) and recently in Great Britain (Walker, 1992).

We would like to thank Maggie Knox and Helen Downer for providing primers and protocols for the sequencing. This work formed part of project X0082, commissioned by the Natural Resources Institute, and was carried out under MAFF licence nos PHF 1185A/99(81), PHF 1185B/10(111) and PHF 1185A/62(11), under the Plant Health (Great Britain) Order, 1987. The Sainsbury Laboratory is supported by the Gatsby Charitable Foundation.

\section{References}

Ahrens, U. \& SeEmüller, E. (1992). Detection of DNA of plant pathogenic mycoplasmalike organisms by a polymerase chain reaction that amplifies a sequence of the $16 \mathrm{~S}$ rRNA gene. Phytopathology 82, 828-832.

AmanN, R. I., KRUmHolz, L. \& STahl, D. A. (1990). Fluorescentoligonucleotide probing of whole cells for determinative, phylogenetic, and environmental studies in microbiology. Journal of Bacteriology 172, 762-770.

Bereswill, S., Pahl, A., Bellemann, P., Zeller, W. \& Geider, K. (1992). Sensitive and species-specific detection of Erwinia amylovora by polymerase chain reaction analysis. Applied and Environmental Microbiology 58, 3522-3526.

Boucher, C. A., Barberis, P. A., Trigalet, A. P. \& Demery, D. A. (1985). Transposon mutagenesis of Pseudomonas solanacearum: isolation of Tn5-induced mutants. Journal of General Microbiology 131, 2449-2457.

Boucher, C. A., van Gijsegem, F., Barberis, P. A., Arlat, M. \& ZisCHEK, C. (1987). Pseudomonas solanacearum genes controlling both pathogenicity on tomato and hypersensitivity on tobacco are clustered. Journal of Bacteriology 169, 5626-5632.

Buddenhagen, I. W., Sequeira, L. \& Kelman, A. (1962). Designation of races in Pseudomonas solanacearum. Phytopathology 52, 726.

COOK, D. \& SequeIRA, L. (1991). The use of subtractive hybridization to obtain a DNA probe specific for Pseudomonas solanacearum race 3. Molecular and General Genetics 227, 401-410.

CoOK, D., Barlow, E. \& SEqueira, L. (1989). Genetic diversity of Pseudomonas solanacearum: detection of restriction fragment length polymorphisms that specify virulence and the hypersensitive response. Molecular Plant-Microbe Interactions 2, 113-121.

COOK, D., Barlow, E. \& SEqueira, L. (1991). DNA probes as tools for the study of host-pathogen evolution: the example of Pseudomonas solanacearum. In Advances in Molecular Genetics of Plant-Microbe Interactions, vol. 1, pp. 103-108. Edited by H. Hennecke \& D. P. Verma. Dordrecht: Kluwer.

Daniels, M. J., Barber, C. E., Turner, P. C., Cleary, W. G. \& SAWCZYC, M. (1984). Isolation of mutants of Xanthomonas campestris pv. campestris showing altered pathogenicity. Journal of General Microbiology 130, 2447-2455.

DeLong, E. F., Wickham, G. S. \& Pace, N. R. (1989). Phylogenetic stains: ribosomal RNA-based probes for the identification of single microbial cells. Science 243, 1360-1363.

DevereuX, J., Haeberli, P. \& SMithies, O. (1984). A comprehensive set of sequence analysis programs for the VAX. Nucleic Acids Research 12, 387-395.

De Vos, P. \& De LeY, J. (1983). Intra- and intergeneric similarities of Pseudomonas and Xanthomonas ribosomal ribonucleic acid cistrons. International Journal of Systematic Bacteriology 33, 487-509.

EdEN-Green, S. J. \& SASTRAatMAdJA, H. (1990). Blood disease present in Java. FAO Plant Protection Bulletin 38, 49-50.

GäUMANN, E. (1923). Onderzoekeningen over de bloedziekte der bananen op Celebes II. Mededeelingen van het Instituut voor Plantenziekten 59, 1-47.
Giovannoni, S. J., DeLong, E. F., Olsen, G. J. \& Pace, N. R. (1988). Phylogenetic group-specific oligodeoxynucleotide probes for identification of single microbial cells. Journal of Bacteriology 170, 720-726.

HaYWARD, A. C. (1991). Biology and epidemiology of bacterial wilt caused by Pseudomonas solanacearum. Annual Review of Phytopathology 29, 65-87.

Innes, M. A., Myambo, K. B., Gelfand, D. H. \& Brow, M. A. D. (1988). DNA sequencing with Thermus aquaticus DNA polymerase and direct sequencing of polymerase chain reaction amplified DNA. Proceedings of the National Academy of Sciences of the United States of America 85, 9436-9440.

OLsson, K. (1976). Experience of brown rot caused by Pseudomonas solanacearum (Smith) Smith in Sweden. EPPO Bulletin 6, 199-207.

Palleroni, N. J. (1984). Pseudomonadaceae. In Bergey's Manual of Systematic Bacteriology, vol. 1, pp. 141-219. Edited by N. R. Krieg \& J. G. Holt. Baltimore: Williams \& Wilkins.

Palleroni, N. J. \& Doudoroff, M. (1971). Phenotypic characterisation and deoxyribonucleic acid homologies of Pseudomonas solanacearum. Journal of Bacteriology 107, 690-696.

Palleroni, N. J., Kunisawa, R., Contopoulou, R. \& Doudoroff, M (1973). Nucleic acid homologies in the genus Pseudomonas. International Journal of Systematic Bacteriology 23, 333-339.

Ralston, E., Palleroni, N. J. \& Doudoroff, M. (1973). Pseudomonas pickettii, a new species of clinical origin related to Pseudomonas solanacearum. International Journal of Systematic Bacteriology 23, $15-19$.

Roberts, S. J., Eden-Green, S. J., Jones, P. \& Ambler, D. J. (1990). Pseudomonas syzygii sp. nov., the cause of Sumatra disease of cloves. Systematic and Applied Microbiology 13, 34 43

Roperos, N. I. (1965). Note on the occurrence of a new disease on cooking banana in The Philippines. Coffee and Cocoa Journal, the Philippines 8, 135-136.

SCHesser, K., Luder, A. \& Henson, J. M. (1991). Use of polymerase chain reaction to detect the take-all fungus Gaeumannomyces graminis, in infected wheat plants. Applied and Environmental Microbiology 57, 553-556.

Seal, S., Elphinstone, J., Skoglund, L. \& Berrios, D. (1992a). Detection of Pseudomonas solanacearum latent infections in seed potatoes during their multiplication in Burundi. ACIAR Bacterial Wilt Newsletter 8, 2-3.

Seal, S. E., Jackson, L. A. \& Daniels, M. J. (1992b). Isolation of a Pseudomonas solanacearum-specific DNA probe by subtraction hybridization and construction of species-specific oligonucleotide primers for sensitive detection by the polymerase chain reaction. Applied and Environmental Microbiology 58, 3751-3758.

SEAL, S. E., Jackson, L. A. \& Daniels, M. J. (1992c). Use of tRNA consensus primers to indicate subgroups of Pseudomonas solanacearum by polymerase chain reaction amplification. Applied and Environmental Microbiology 58, 3759-3761.

WALKER, D. (1992). Potato brown rot. Plant Disease Notice no. 73. Harpenden: Central Science Laboratory.

Welsh, J. \& MCClelland, M. (1991). Genomic fingerprints produced by PCR with consensus tRNA gene primers. Nucleic Acids Research 19, 861-866.

WINSHIP, P. R. (1989). An improved method for directly sequencing PCR amplified material using dimethyl sulphoxide. Nucleic Acids Research 17, 1266.

WOESE, C. R. (1987). Bacterial evolution. Microbiological Reviews 51, 221-271.

Young, J. P. W., Downer, H. L. \& Eardly, B. D. (1991). Phylogeny of the phototrophic Rhizobium strain BTAil by polymerase chain reaction-based sequencing of a 16S rRNA gene segment. Journal of Bacteriology 173, 2271-2277.

Zarda, B., Amann, R., Wallner, G. \& Schleifer, K.-H. (1991) Identification of single bacterial cells using digoxigenin-labelled rRNA-targeted oligonucleotides. Journal of General Microbiology 137, 2823-2830. 